\title{
Altitudinal records of data-deficient and threatened frog species from the Atlantic Rainforest of the Serra dos Órgãos mountains, in southeastern Brazil
}

\author{
Siqueira, CC. ${ }^{a, b *}$, Vrcibradic, $D .^{c}$ and Rocha, CFD. ${ }^{b}$ \\ aPrograma de Pós-graduação em Ecologia, Universidade Federal do Rio de Janeiro - UFRJ, \\ Av. Carlos Chagas Filho, 373, Bl. A, CEP 21941-902, Rio de Janeiro, RJ, Brazil \\ 'Departamento de Ecologia, Universidade do Estado do Rio de Janeiro - UERJ, \\ Rua São Francisco Xavier, 524, CEP 20550-011, Rio de Janeiro, RJ, Brazil \\ 'Departamento de Zoologia, Universidade Federal do Estado do Rio de Janeiro - UNIRIO, \\ Av. Pasteur, 458, CEP 22240-290, Rio de Janeiro, RJ, Brazil \\ *e-mail: carlacsiqueira@yahoo.com.br \\ Received April 04, 2012 - Accepted May 05, 2012 - Distributed February 28, 2013
}

\begin{abstract}
Threatened species are usually the focus of conservation efforts and funding programs, but little attention is given to species considered "data-deficient" (DD), contradicting the IUCN's recommendation to give them the same degree of attention as threatened taxa (Pimenta et al., 2005). Here, we present information on the occurrences of some anuran species currently considered as data-deficient, near threatened or endangered (and some species which are not on the IUCN list), based on data gathered during surveys
\end{abstract}

conducted from November 2007 to March 2010 in the Atlantic Rainforest of the Serra dos Órgãos mountain range region, in the state of Rio de Janeiro, Brazil. Sampling was carried out in four areas: the Reserva Ecológica de Guapiaçu (REGUA; $22^{\circ} 24^{\prime} \mathrm{S}, 42^{\circ} 44^{\prime} \mathrm{W}$ ) and three sites within the Parque Estadual dos Três Picos: Fazenda Santa Bárbara (FSB; $22^{\circ} 25^{\prime} \mathrm{S}$ and $42^{\circ} 34^{\prime} \mathrm{W}$ ), Theodoro de Oliveira (TO; $22^{\circ} 22^{\prime} \mathrm{S}$ and $42^{\circ} 33^{\prime} \mathrm{W}$ ), and Baixo Caledônia (BC; $22^{\circ} 21^{\prime} \mathrm{S}$ and $42^{\circ} 34^{\prime} \mathrm{W}$ ). Sampling was

Table 1. Anuran species recorded in four areas within the region of the Serra dos Órgãos mountains, in southeastern Brazil (see text for abbreviations of sampling localities). Numbers in those columns represent the elevations (m) where frogs were found. Species endemic to the state of Rio de Janeiro (RJ) and to the Serra dos Órgãos (SO) are marked with an "X". Conservation status of species (data-deficient - DD; near threatened - NT; endangered - EN) follows IUCN (2011).

\begin{tabular}{|c|c|c|c|c|c|c|c|}
\hline Species & REGUA & FSB & TO & BC & $\mathbf{R J}$ & SO & IUCN \\
\hline \multicolumn{8}{|l|}{ BRACHYCEPHALIDAE } \\
\hline Brachycephalus garbeanus & & & 1400 & $1600-1900$ & $\mathrm{X}$ & $\mathrm{X}$ & \\
\hline Brachycephalus sp. n. & & & $1100-1200$ & & $\mathrm{X}$ & $\mathrm{X}$ & \\
\hline Ischnocnema erythromera & & & $1100-1400$ & & $\mathrm{X}$ & $\mathrm{X}$ & DD \\
\hline Ischnocnema holti & & & $1100-1300$ & 1600 & $\mathrm{X}$ & & DD \\
\hline Ischnocnema sp. (gr. lactea) & & & 1300 & & $\mathrm{X}$ & $\mathrm{X}$ & \\
\hline \multicolumn{8}{|l|}{ CYCLORAMPHIDAE } \\
\hline Cycloramphus brasiliensis & $100-600$ & $600-700$ & & & $\mathrm{X}$ & & NT \\
\hline \multicolumn{8}{|l|}{ HEMIPHRACTIDAE } \\
\hline Flectonotus sp. & & & & $1600-1900$ & $\mathrm{X}$ & $\mathrm{X}$ & \\
\hline Gastrotheca ernestoi & & & & 1900 & $\mathrm{X}$ & & DD \\
\hline \multicolumn{8}{|l|}{ HYLIDAE } \\
\hline Aplastodiscus eugenioi & $100-300$ & & & & & & NT \\
\hline Hypsiboas secedens & 200 & & & & $\mathrm{X}$ & & DD \\
\hline \multicolumn{8}{|l|}{ HYLODIDAE } \\
\hline Crossodactylus aeneus & $100-300$ & 600 & & & & & DD \\
\hline Hylodes charadranaetes & 600 & $600-900$ & $1100-1400$ & & $\mathrm{X}$ & & DD \\
\hline Hylodes pipilans & $300-500$ & & & & $\mathrm{X}$ & & DD \\
\hline \multicolumn{8}{|l|}{ MICROHYLIDAE } \\
\hline Chiasmocleis carvalhoi & 300 & & & & & & EN \\
\hline \multicolumn{8}{|l|}{ STRABOMANTIDAE } \\
\hline Holoaden pholeter & & & $1200-1400$ & & $\mathrm{X}$ & $\mathrm{X}$ & DD \\
\hline
\end{tabular}


done using visual encounter surveys (total of 1,000 hours of searching) and pitfall traps (60-liter buckets; total of 600 traps-days) at 14 altitudinal levels ranging from 100 to $1900 \mathrm{~m}$.

Among the 62 frog species found during the study, eight are presently categorised by the IUCN (2011) as datadeficient, two as "near threatened", one as "endangered", and four are not on the IUCN list (Table 1), as they represent recently revalidated (Brachycephalus garbeanus) or still undescribed taxa (Brachycephalus sp., Ischnocnema sp., Flectonotus sp. (see Siqueira et al., 2011). Of these 15 species, $12(=80 \%)$ are currently known only from the state of Rio de Janeiro, and six $(=40 \%)$ are considered endemic to the Serra dos Órgãos region (Table 1). Most of these species were recorded in just one or two locations, within a small elevational range. Regarding reproductive modes, seven of the species (Brachycephalus spp., Ischnocnema spp., Holoaden pholeter, and Gastrotheca ernestoi) have direct development and lay eggs on the moist leaf litter of the forest floor, whereas five (Crossodactylus aeneus, Hylodes spp., Cycloramphus brasiliensis, and Aplastodiscus eugenioi) depend on clean, lotic water bodies for reproduction. We hope these data improve the knowledge on these poorly known species and stimulate future long-term studies with them, contributing to conservation efforts for amphibians in the Atlantic Rainforest.

Acknowledgements - We thank the INEA, Nicholas Locke and Alexander Davis for the permissions for working at the studied sites. CFDR received resources from the CNPq (304791/20105 and 470265/2010-8) and FAPERJ ("Cientistas do Nosso Estado"; E-26102.765/2012). This project also benefitted from funding from the Fundação Biodiversitas/CEPAN and RAN/ ICMBio (0158A/012006). CCS received PhD (141555/2008-4) and postdoctoral (150151/2012-8) grants from CNPq. We also thank J.P. Pombal Jr., C. Canedo, C.A.G. Cruz, B.V.S. Pimenta and M. Targino (MNRJ) for frog identifications.

\section{References}

International Union for Conservation of Nature - IUCN, 2011. The IUCN Red List of Threatened Species. version 2011.2. Available from: <http://www.iucnredlist.org > Access in: 01 Apr. 2012.

PIMENTA, BVS., HADDAD, CFB., NASCIMENTO, LB., CRUZ, CAG. and POMBAL JUNIOR, JP., 2005. Comment on "Status and trends of amphibian declines and extinctions worldwide". Science, vol. 309, p. 1999.

SIQUEIRA, CC., VRCIBRADIC, D., DORIGO, TA. and ROCHA, CFD., 2011. Anurans from two high-elevation areas of Atlantic Forest in the state of Rio de Janeiro, Brazil. Zoologia, vol. 28, no. 4 , p. $457-464$. 